\title{
The 'Civilizing' Empire: The European Union and the MENA Neighborhood
}

\author{
By Yannis A. Stivachtis*
}

This article provides a critique of the European Union's Neighborhood Policy (ENP) as it applies to the Middle East and North Africa (MENA) region. It argues that the EU constitutes a modern form of empire that seeks to 'civilize' its external environment and that the ineffectiveness of the ENP is partially due to the EU's imperial attitudes towards third countries and its self-image as a 'civilizing' actor whose mission is to transform the MENA states into political entities resembling the image of its own member states. EU's 'civilizing' mission is mainly to promote its political and security interests and thus denying to take adequate account of the interests and values of the individual MENA states or the differentiation among them in economic, socio-cultural, and political terms. To achieve its objectives, the EU utilizes its image as a 'civilian', 'normative' and 'market power' and the instrument of conditionality.

Keywords: European Union, empire, conditionality, civilizing process, civilian power, normative power, market power, MENA, ENP.

\section{Introduction}

It has been widely recognized that the normative aspirations of the European Union (EU) in expanding the "zone of prosperity, stability, and security" beyond its borders have not been translated into success (Singh 2016: 32). The recent Arab uprisings demonstrated more than anything else the shortcomings of the European Union's Neighborhood Policy (ENP) in relation to the countries of the Middle East and North Africa (MENA) (Leonard 2014). As a result, new proposals have been put forward for more inclusive, responsive, and flexible EU policies towards the MENA region.

The purpose of this article is not to discuss the ENP's institutional shortcomings in relation to the MENA countries as this has been already done by other scholars and analysts (Gstöhl 2015, 2016, Tholens and Groß 2015, Borzel and Van Hullen 2014, Kochenov 2014, Leino and Petrov 2009, Bosse 2007). Instead, this article seeks to demonstrate that the ineffectiveness of the ENP is partially due to the EU's imperial attitudes towards third countries and its self-image as a 'civilizing' actor whose mission is to transform the MENA states into political entities resembling the image of its own member states. In so doing, the article is divided into four parts. The first part discusses the EU's 'civilizing' discourse and identifies the tools available to the Union to achieve its 'civilizing' mission. The second section examines the EU's policy of conditionality as the main instrument through which the Union seeks to achieve

${ }^{*}$ Director \& Professor, International Studies Program Virginia Tech - Virginia Polytechnic Institute \& State University, USA. 
its political and security objectives by transforming its external environment. The third part discusses the EU's conceptualization of 'order', while the final section focuses on how the EU utilizes its conditionality policy to create order in its MENA neighborhood by transforming the regional states.

\section{The 'Civilizing' Empire and Its Tools}

The empire discourse has been primarily related to the role and position of the United States in global affairs. However, the EU's enlargement and neighborhood policies have brought the empire discourse into European Union studies. In this respect, the debate has been about the nature of EU power, as well as its strategy to achieve its foreign policy objectives.

It is often argued that the EU is an international actor that seeks to promote its norms and values in world affairs (Cremona 2011, Diez 2005, Manners 2002, Whitman 1998, Stivachtis 2007) and to contribute to global order by spreading institutional structures and rules of legitimate behavior (Elgstrom and Smith 2006, Orbie 2009). It has been shown (Manners 2002: 242) that EU external policies are based on the core norms that form its own identity, such as peace, liberty, democracy, rule of law, and respect for human rights and fundamental freedoms, as well as social solidarity, anti-discrimination, sustainable development and good governance.

However, while its member states see the EU as an agent of peace, democracy, development, and good governance (Stivachtis et al. 2013), other states view the Union as an actor possessing considerable power and resources and whose policies seek to determine international behavior by prescribing what constitutes legitimate behavior, dictating international rules, and imposing domestic constraints on other sovereign actors (Zielonka 2011). Among other things, the EU is often perceived as a kind of empire with a post-modern version of 'mission civilisatrice' (Zielonka 2013: 36, Del Sarto 2016). Like all empires, the EU has a civilizing narrative since it claims to be an indispensable agent of modernity and peace in Europe and beyond (Zielonka 2015).

It has been argued that the EU constitutes a modern form of empire, which displays imperial attitudes and tendencies in its relations with third states. Despite some differences, the EU shares many common characteristics with former empires (Stivachtis 2015). Zielonka (2006, 2013) has argued that the EU represents a vast territorial unit with the ability to "influence (if not manipulate) the international agenda and shape the notion of legitimacy (if not normality) in various parts of the world, and especially in its neighborhood". In other words, the EU seeks to do what all historical empires used to do, namely to exercise influence and control over diverse peripheral actors through formal annexations (EU membership) or various forms of informal domination reflected in a number of policies, such as the ENP. In this sense, the EU's normative discourse can be understood as a device to legitimize the Union's imperial policies in its neighborhood and beyond. 
Moreover, Stivachtis (2008) has argued that the EU is a polity that seeks to 'civilize' its external environment and this process is reminiscent of the 'civilizing' process associated with the historical expansion of the European society of states and its gradual transformation to the contemporary global international society (Bull and Watson 1984, Watson 1992, Dunne and Reus-Smit 2017). The core instrument of the historical European-led 'civilizing' process was the standard of 'civilization' which included the conditions under which nonEuropean states could be admitted to the expanding European international society (Gong 1984, Schwartzenberger 1955, 1976). Stivachtis (2015) has argued that a comparison can be drawn between the way in which the historical European international society sought to transmit its norms and values through the application of the standard of 'civilization' with the manner in which the EU has attempted to transmit its own values and norms through its policy of conditionality as it applies to its enlargement and neighborhood policies.

Feuer (1989: 4) identifies two major subtypes of imperialism: the first is 'regressive imperialism' identified with pure conquest, unequivocal exploitation, extermination or reductions of undesired peoples, and the settlement of desired peoples into such territories. However, EU actions are associated with the second type of imperialism identified by Feuer, namely 'progressive imperialism'; a concept that is founded upon a cosmopolitan view of humanity that advocates the spread of 'civilization' to allegedly 'backward' societies to improve living standards and promote civil and political liberties in territories lying beyond the legal boundaries of the imperial polity, with the allowance of people living in those territories to assimilate into the imperial society.

This brings to the forefront the question of capabilities available to the EU to achieve these objectives and subsequently the question of the EU's identity as a 'civilian', 'normative power' and 'market power'.

'Civilian power' has been defined as involving three key features: the centrality of economic power to achieve political goals; the primacy of diplomatic cooperation to solve international problems; and the willingness to use legally binding supranational institutions to achieve international progress (Twitchett 1976: 1-2). However, the connection between the EU as 'empire' and EU as a 'civilian power' can be better understood with reference to Hans Maull's definition of a civilian power as a state "... whose conception of its foreign policy role and behavior is bound to particular aims, values, principles, as well as forms of influence and instruments of power in the name of a civilization of international relations" (Maull 1990: 92-93). According to this definition, EU's civilian power lies on the use of its norms, values, and principles in an effort to 'civilize' international relations. In this context, EU acts as the 'civilizer' whose duty is to create a peaceful and stable international order by 'civilizing' the 'others' thereby establishing a hegemonic and imperial type of 'civilizer-civilizee' relationship.

To celebrate the $50^{\text {th }}$ anniversary of the Schuman Declaration, the EU distributed information material which made reference to the EU as a 'civilian power' (EC 2000). Romano Prodi (2000: 3) also made a reference to the status of the EU as a global civilian power by stating that "We must aim to become a 
global civil power at the service of sustainable global development. After all, only by ensuring sustainable global development can Europe guarantee its own strategic security".

However, a more comprehensive understanding of the EU's role in international affairs might be gained by reflecting on its normative power, which constitutes a discursive construction of the EU employed by most EU politicians and technocrats. As Thomas Diez (2005: 619) puts it, “...there may well be disagreement about the development of the EU's military capacities between Council and Commission, and between different member states and different directorate-generals, yet the representation of Europe as a force for peace and well-being is nearly consensual".

Normative power refers to particular power 'means'. In other words, it is not a power that relies on military force, but a power in which norms themselves achieve what otherwise is done by military arsenals or economic incentives (Diez 2005: 614). This does not mean that normative power cannot exist alongside other forms of power. For example, Helene Sjursen (2004: 122) has pointed out that it is entirely possible that military force is used to back up the spread of normative and civilian values.

According to Diez (2013: 195), debates about the character of EU's identity as a global actor do not take into account or underestimate the 'power' that lies in the representation of the EU as a 'normative power'. Similarly, Johann Galtung (1973: 33) has argued that ideological power is "powerful because the power sender's ideas penetrate and shape the will of the power-recipient' through the media of culture". Diez (2013: 204) suggests that not only is the success of this EU representation a precondition for other actors to agree to the norms advocated by the EU, but it also constructs an EU identity against an image of 'Others'. Consequently, the discourse of the EU as a normative power not only constructs a particular EU 'self' but seeks at the same time to change 'Others' through the spread of the EU's own norms. For Diez, this has important implications for the way the EU and its policies treat those 'Others', and the degree to which its adherence to its own norms is scrutinized within the Union; a fact that reminds us of the failure of the European powers to observe their own standards while demanding from non-European states to fulfill the historical standard of 'civilization'.

Following the end of the Cold War, the EU has found itself in a situation similar to the one that the U.S. found itself during the first part of the twentieth century when President Wilson's aim was to spread peace throughout the world so that military interventions and political interference would no longer be necessary. The idea was to do so by binding normative commitments rather than military means. The EU's Security Strategy (EC 2003a, 2008) and Global Strategy (EC 2015b) makes it clear that a peaceful and stable global order requires the creation of democratic states and the spread of European values and norms across the globe.

In response to the 'normative power Europe' debate, which has mostly focused on political values, Damro (2012: 682) suggests that the EU may also be conceptualized as a 'market power Europe' which 'exercises its power through 
the externalization of economic and social market-related policies and regulatory measures". The European Commission itself has also noted that the internal market is "a powerful engine to promote EU high quality rules and values around the world" because "...through the enlargement process and the European Neighbourhood Policy, the Community rulebook is gradually being adopted across large parts of the European continent", and the internal market is "increasingly serving as a reference point in third countries as well as in global and regional fora" (EC 2008: 5).

However, the ideas of a 'normative', 'market' or 'civilian power Europe' are not so innocent in the sense that the transmission of European norms and values is one way of shaping international order and serves as an alternative to military means (Telo 2006). Irrespective of EU's international identity, any single form of power among those discussed above represents a form of hegemonic power, defined as the power to shape the values, policies and practices of others.

\section{European Union and Conditionality}

The pressures of international anarchy and the need of non-EU states to maintain close relations with the Union in order to serve their political and economic interests have enabled the EU to define certain expectations and impose certain standards of behavior on those states. EU pressures aimed at altering attitudes and policies can be equally applicable to all states irrespective of whether or not they seek EU membership.

Conditionality represents a deliberate effort to determine an outcome through external pressure. This is achieved by specifying conditions or even preconditions for support, involving either promise of material aid or political opportunities. A particular version is 'democratic conditionality' that emphasizes respect for and adherence to democratic rules, procedures, and values. The EU has elaborated an extensive policy of 'democratic conditionality' and has considerable leverage because the prize for compliance on the part of applicant states is full EU membership and on the part of countries that wish to establish close relations with the EU is often financial and development assistance.

Conditionality has been an essential feature of the EEC enlargement since the 1960s although the formulation of 'political conditions' has undergone considerable evolution over time expanded to include substantive democratic requirements. It was the European Parliament (EP) that first issued a report on the necessary political and institutional conditions for EEC membership and association status which stated that "only states which guarantee on their territories truly democratic practices and respect for fundamental rights and freedoms can become members of the Community". The report also warned that "states whose governments do not have democratic legitimization and whose people do not participate in government decisions, either directly or through fully elected representatives, cannot aspire to be admitted into the circle of nations which form the European Communities" (as cited in Pridham 2005: 30).

Above and beyond everything else, it was the end of the Soviet Union, the 
collapse of communism in Eastern Europe, the subsequent request of Eastern and Central European countries for EU membership, and the request of former Soviet states for close relations with the EU that made 'conditionality' a central feature of the EU enlargement and neighborhood policies.

Specifically, since the end of the Cold War, the EU (then EEC) has made assistance and institutional ties conditional on the fulfillment of democratic and human rights standards. For example, after the dissolution of the Soviet Union, the European Commission clearly stated that "negotiating ... new types of agreements has to be subject to political conditions" (as cited in Schimmelfenning et al. 2006: 30)' In May 1992, the European Council underscored that "respect for democratic principles and human rights ... as well as the principles of a market economy, constitute essential elements of cooperation and association agreements between the Community and its CSCE partners" (as cited in Schimmelfenning et al. 2006: 30). Since then, the EU added a clause to the agreements that stipulated their suspension if partner countries failed to comply with these principles. In November 1992, the European Council approved guidelines for PHARE, which made the provision of aid conditional upon the "state of advance of the reforms in each of the beneficiary countries". In July 1993, the new regulations of the aid program for the former Soviet republics (TACIS) made it clear that "the level and intensity of the assistance will take into account the extent and progress of reform efforts in the beneficiary country" (as cited in Schimmelfenning et al. 2006: 30). Finally, during the Copenhagen Summit in June 1993, the European Council identified the essential political requirements for accession to the European Union. Apart from defining the political conditions, the Copenhagen Summit specified also the economic conditions that should be met before a candidate country is accepted as an EU member. Specifically, in order to quantify EU norms and values, the Copenhagen European Council established the following criteria:

1. Membership requires that the candidate country has achieved stability of institutions guaranteeing democracy, the rule of law, human rights, and respect for the protection of minorities.

2. Membership requires the existence of a functioning market economy as well as the capacity to cope with competitive pressure and market forces within the Union.

3. Membership presupposes the candidate's ability take on the obligations of membership including adherence to the aims of political, economic and monetary union.

Since the Copenhagen Summit, additions have been made to the original criteria, notably in the inclusion of the fight against corruption.

Although one should expect a well-considered integrated approach to conditionality by the EU, in effect, there is no clear meaning attached to it. Thus, implementation of 'political conditionality' tends to be disaggregated. Moreover, the evolving definition of 'political conditions' has been incremental and sometimes ad hoc (Pridham 2002a: 206-7). This explains the seeming 
ambiguity in the European commission's Annual Reports which invariably say that given countries "fulfill the Copenhagen political criteria" but still need to make further progress in meeting particular conditions. Thus, as in the case of the historical standard of 'civilization' where European powers expected nonEuropean states to fulfill standards that the European powers themselves did not observe, the EU has been criticized for demanding higher political standards of candidate countries compared with its own Member States (Pridham 2002b: 957).

Studying EU's enlargement and neighboring policies, one may observe that the processes involved are not very different from the process of the historical expansion the European international society, while EU accession and association politics have strong commonalities with the historical standard of 'civilization' (Behr 2007: 239). As in the nineteenth and early twentieth centuries, when the European powers had to define the conditions that non-European states had to fulfill in order to gain entry into international society, EU Member States had to define the conditions that would shape their relations with third states. Like the standard of 'civilization', conditionality is an expression of the assumptions used to distinguish those states that the EU could be associated with from those that could not. Those who would fulfill the political and economic conditions set by the EU would be brought inside or closer while those which would not conform will be left outside or will be marginalized. Like the non-European states before, non-EU states interested to be associated with the EU had to fulfill EU conditionality and learn to adjust themselves even at some significant cost to their own societies.

What conditionality and the historical standard of 'civilization' have in common is their tendency to create and support an international liberal political and economic system. It is not a coincidence, that requirements included in the standard of 'civilization' are also included in EU conditionality. For example, the standard of 'civilization' included: protection of basic human rights of Western nationals such as life, liberty, property, freedoms of travel, commerce, and religion; opening of domestic markets to foreign traders and merchants; organized and effective governmental bureaucracy; Western-style system of domestic law with impartial administration of justice; ability to engage in international relations and abide by international law; conform to Western customs, norms, and mores; and sources of international law central to applying the old standard of civilization to non-Western countries (Gong 1984: 14-15). Conditionality includes: protection of basic civil and political rights; liberalization of markets for trade in goods, services and investment capital; 'good governance' and anti-corruption measures; emphasis on the rule of law within countries, and linking governmental legitimacy to presence of democracy; stress on a state's ability to participate in the process of globalization and to follow international legal regimes adopted to deal with globalization issues; pressure on states to adopt Western individualism, consumerism, and secularism at the expense of traditional practices; and sources of international law, and international legal regimes created with them, central to applying the new standard of civilization globally. Moreover, the EU's monitoring and evaluation procedures have been compared with the tradition of imperial bureaucracy in the nineteenth century (Cooper and Stoller 2011: 11). 
According to Behr (2007: 240), three general features are central to both the standard of 'civilization' and EU conditionality: first, European states perceive themselves as those who authoritatively define the standards; second, the existence of regulations which define different steps and paces of cooperation between European and non-European states today resemble the unequal treaties of the nineteenth century; and third, a geopolitical model projecting a world order where European states occupy the center while less politically developed states occupy different zones in the periphery. All three features are integral part of EU accession and association politics, as well as the EU's Neighborhood Policy.

\section{European Union's Conceptualization of Global Order}

In order to promote its political and economic interests and secure itself from outside threats, the EU needs to regulate and manage its external environment by exporting - through its neighborhood policy - its norms, rules, values, and practices thereby gradually expanding the boundaries in which these norms, rules, values, and practices apply. The EU's policy of conditionality is fundamental to this process as only states willing to fulfill EU conditions will be rewarded while the rest will be marginalized. But this process is similar to the one associated with the historical expansion of the European society of states with conditionality replacing the old standard of 'civilization'. In this context, EU relations with states in the European periphery is viewed as an example of a 'civilizing' process that seeks to transmit the values of the core/center to the rest of the world (Linklater 2005a, 2005b, 2016).

Following the acceptance of the Nobel Peace Prize award on the 12 October 2012, José Manuel Barroso, President of the European Commission, and Herman Van Rompuy, President of the European Council, jointly issued a statement according to which "... over the last sixty years, the European Union has reunified a continent split by the Cold War around values of respect for human dignity, freedom, democracy, equality, the rule of law and respect for human rights". The presidents explicitly illustrated the EU's conceptualization of global order as they elaborated: "...these are also the values that the European Union promotes to make the world a better place for all. The European Union will continue to promote peace and security in the countries close to us and the world at large" (EC 2012). In other words, the EU's conceptualization of global order necessitates the spread and adoption of its own values and norms.

However, it was not until the Maastricht Treaty in 1991 that the EU specified its foreign policy objectives. The Draft Constitutional Treaty proclaimed that the EU's policies should aim at "... preserving peace, preventing conflicts and strengthening international security" and that in doing so, the EU would be guided by principles that are rooted in traditions of "democracy, human rights, fundamental freedoms and the rule of law" (Tocci 2007: 7). These principles were reaffirmed in the Lisbon Treaty.

The range of conditionality-related instruments available to the EU continues to increase in size and scope. The use of these instruments is guided by the 
objectives set out in the European Security Strategy (ESS) that was adopted in December of 2003, as well as in the EU's Global Strategy adopted in 2015. These documents established principles and set clear objectives for advancing the EU's security interests based on the EU's core values. According to the ESS, the two fundamental pillars of the EU's approach are: building security in the EU's neighborhood and promoting an international order based on effective multilateralism (EC 2003a: 9). The EES has defined the neighborhood "as a key geographical priority of EU external action..." (EC 2003a: 9). As Nathalie Tocci (2007: 7) argues, the ENP seeks to promote EU values "as a means to spread stability, security and prosperity in the southern and eastern neighbourhoods ... and to strengthen the EU's contribution to the solution of regional conflicts".

One of the most significant security threats identified in ESS has been bad governance (EC 2003a: 4). For example, the ESS (EC 2003a: 10) proclaims that

"The quality of international society depends on the quality of the governments that are its foundation. The best protection for our security is a world of well-governed democratic states. Spreading good governance, supporting social and political reform, dealing with corruption and abuse of power, establishing the rule of law and protecting human rights are the best means of strengthening the international order...".

In other words, the best protection for the EU's security is a world of well-governed democratic states and EU policies aiming at creating a stable international order are to be guided by a set of principles, values, and norms that reflect those of the European Union. To prevent state failure that has the potential of leading to organized crime and/or terrorism, the EU uses a range of tools, including political and economic conditionality, to ensure the establishment of well-governed democratic states.

Moreover, according to the ESS, for states that have placed themselves outside the bounds of international society, it is desirable that they rejoin the international community and that the EU should be ready to provide assistance. However, for those "who are unwilling to do so should understand that there is a price to be paid, including in their relationship with the European Union" (EC 2003a: 10).

\section{Exporting Norms and Values: EU Conditionality, ENP and the MENA States}

The broad EU normative basis has been developed over time through a series of declarations, treaties, policies and conditions. The five 'core' EU norms are expressed in the preamble and founding principles of the Treaty of the European Union (TEU) and include the acquis communautaire, the acquis politique, democracy, the rule of law, and respect for human rights and fundamental freedoms. Moreover, the EU identified the promotion and consolidation of democracy, as well as the respect for human rights and fundamental freedoms as its foreign and development policy objectives and 
proclaimed its commitment to pursuing these norms in accordance with the European Convention of Human Rights (ECHR) and the principles of the United Nations Charter. Democracy, rule of law, social justice and respect for human rights are all norms enshrined in Lisbon Treaty and represent crucial constitutive factors determining the EU's international identity (Manners 2002: 243).

Facing political and social instability due to their economic problems, the countries of the MENA region sought to establish closer relations with the European Union. The EU was quick to realize that its security was intimately connected to the stability of the countries geographically embedded in its neighborhood. The establishment of the ENP and the inclusion of MENA states into it reflected the need and interests of all parties concerned. However, the presence and operation of asymmetrical interdependence in favor of the EU enabled the Union to demand the implementation of certain standards and policies on the part of the MENA states, seeking in this way to transmit elements of the EU order beyond the EU borders.

While candidate states have to follow the EU acquis, there has been discussion regarding the specific role that the EU should take in the promotion of democratization in countries that are neither acceding countries nor candidates. The ENP is meant to allow EU Members States to work "together with partner countries, to define a set of priorities, whose fulfillment will bring them closer to the European Union" (EC 2004). Even though candidacy may not be a short-term goal for some of these states, the EU nevertheless emphasizes the importance for building communication and shared values related to issues like security, democracy, human rights, political freedom, and trade liberalization. According to the EU, stability for not just the member states, but also the surrounding regions can be ensured much more effectively with attention paid to these areas, which are clearly interrelated and hard to untangle from one another.

According to the European Commission (2003b), there were many areas and situations that required attention in the aspect of assessing democratization and the protection of human rights. Among them was a noticeable deficit in governance, which restricted the cultivation of shared democratic values. Following the Communication from the European Commission to the Council and the European Parliament, the ENP was developed in 2004 with the objective of strengthening the prosperity, stability and security of the EU and its neighboring states. As such, it was based on the values of democracy, rule of law and respect of human rights. The ENP is mainly a bilateral policy between the EU and each partner country. However, it is complemented by regional multilateral co-operation initiatives, such as the Union for the Mediterranean (formerly known as the Euro-Mediterranean Partnership or Barcelona Process).

In the ENP framework, the EU uses financial and diplomatic means to ensure that there is a move towards democratization in neighboring (MENA) states. In other words, the EU uses a strategy of positive reinforcement where the reward for desired behavior is financial assistance. MENA states, in order to reap the benefits of the ENP must show commitment to the respect of human rights, 
political freedoms, and democratization. Moreover, to take full advantage of the various benefits of the ENP, the Union's MENA neighbors must pledge an adherence not only to human rights, but also to the values of democracy that the Union promotes.

Central to the ENP are the bilateral 'Action Plans' between the EU and each ENP/MENA partner, which set out an agenda of political and economic reforms. Action Plans reflect each partner's needs and capacities, as well as the EU's interests. Under the Action Plans, the EU works together with its MENA partners to develop democratic, socially equitable and inclusive societies. Because the development of civil society is seen as playing a fundamental role in contributing to democracy and good governance building in partner countries, the EU supports organizations via its Civil Society Facility. Yet, the European Commission provides financial support in grant form to partners, while the European Investment Bank and the European Bank for Reconstruction and Development complement the Commission's support through loans.

The ENP builds upon the legal agreements in place between the EU and the partner in question: Partnership and Cooperation Agreements (PCA) or Association Agreements (AA). Within the ENP, the EU offers its MENA neighbors a privileged relationship, building upon a mutual commitment to common values, namely democracy and human rights, rule of law, good governance, market economy principles and sustainable development. Implementation of the ENP is jointly promoted and monitored through the Committees and sub-Committees established in the frame of the PCA or AA agreements.

As some had already predicted (Sasse 2008), this EU 'top-down', 'one size fits all' approach failed to produce the expected results. The strong contestation of ENP conditionality by the MENA countries in conjunction with the Arab Spring-related events convinced the EU to adopt a revised ENP with special emphasis on support to civil society (EC 2011a, 2011b). The relevant ENP Communication called for a "greater political role of non-state actors" and "a partnership with societies" (EC 2011b: 5). To encourage and support political actors who sought political change in their countries, the European Commission established the European Endowment for Democracy (EED) in 2012. Apart from supporting local actors, including political movements, journalists and NGOs, the EED has provided the forum where ENP/MENA states share their experiences with the states of the Central and Eastern European Countries (CEECs) that went through a significant political, social, and economic transformation on their way to becoming EU members. It has been argued that CEECs had important comparative advantages because, unlike some of the EU Members States, they were not colonial powers (Giusti and Fassi 2014: 119).

In sum, the revised ENP put a strong focus on the promotion of 'deep and sustainable' democracy, accompanied by inclusive economic development. 'Deep and sustainable' democracy includes free and fair elections, freedom of expression, of assembly and of association, judicial independence, fight against corruption and democratic control over the armed forces. The EU also stressed the role of civil society bringing about deep and sustainable democracy. 
With the revised ENP, the EU unveiled its 'more for more' principle, under which the Union will develop stronger partnerships with those MENA states that make greater progress towards democratic reform. The 'more for more' principle applies to all incentives proposed by the EU: policy developments as well as to financial assistance. The European External Action Service and the European Commission publish each year the ENP Progress Reports. The assessments contained in these Reports form the basis for EU policy towards each ENP/MENA partner under the 'more for more' principle. Thus the level of ambition of the relationship depends on the extent to which these values are shared. Countries determinedly embarking on political reforms are offered, in addition to the incentives available to other partners, elements of market access: economic integration and development (DCFTAs), mobility of people (mobility partnerships), and a greater share of the EU financial support. In this context, the Commission has decided to set up specific programs both for the Eastern (EAPIC) and Southern (SPRING) neighbors that will allocate extra financial support only to those neighbors taking clear and concrete steps on political reforms.

Nevertheless, the revised ENP failed to recognize and address the nature of economic and political challenges facing the MENA region as a whole (Morillas and Eduard 2012), while inconsistencies characterizing the EU's views of political transformation have created a situation of conceptual fuzziness. As a result, in 2015 the EU launched a new effort to revive the ENP with the European Commission calling for "a need to understand better the different aspirations, values, and interests of our partners" (EC 2015a).

\section{As an Epilogue}

The purpose of this article was to demonstrate that the ineffectiveness of the ENP policy is partially due to the EU's imperial attitudes towards third countries and its self-image as a 'civilizing' actor whose mission is to transform the MENA states into political entities resembling the image of its own member states. In so doing, the article examined the EU's 'civilizing' discourse, discussed the tools available to the Union to achieve its 'civilizing' mission giving particular emphasis to the EU's policy of conditionality as the main instrument through which the Union seeks to achieve its political and security objectives by transforming its external environment, analyzed the EU's conceptualization of 'order' and discussed how the EU utilizes its conditionality policy to create order in its MENA neighborhood by transforming the regional states.

Moreover, a comparison was introduced between the process of the historical expansion of the European society of states and the EU external actions, especially those pertaining to the EU enlargement and neighborhood policies. Given the similarity between the European historical 'civilizing' process and the ENP process, no surprisingly, the main reasons for which EU norms and values have been strongly contested by MENA states are the same reasons 
that led to the abolition of the standard of 'civilization: first, ENP conditionality has been viewed as establishing an unequal relationship between the EU and the MENA states; and second, the EU has attempted to superimpose its conditions on the ENP states; a 'top-down', 'one size fits all' approach that did not involve the active participation of the native civil societies and which has neither taken into account the diverse social, political, cultural and economic conditions facing the MENA states, nor their competing values, nor their lack of capacity or willingness to absorb the EU values. Therefore, a more effective engagement with the MENA region would require the EU to abolish neocolonial attitudes reflecting a 'civilizer-civilizee', 'teacher-pupil' relationship and instead being more open to the perceptions and viewpoints of its MENA partners cultivating at the same time a relationship of mutual respect and equal partnership with them.

\section{References}

Behr H (2007) The European Union in the legacies of imperial rule? EU accession politics viewed from a historical comparative perspective. European Journal of International Relations 13(2): 240-91.

Borzel T, Van Hullen V (2014) One voice, one message, but conflicting goals: cohesiveness and consistency in the European neighborhood policy. Journal of European Public Policy 21(7): 1033-1049.

Bosse G (2007) Values in the EU's neighborhood policy: political rhetoric or reflection of a coherent policy? European Political Economy Review 7: 38-62.

Bull H, Watson A (1984) The Expansion of International Society. Oxford: Clarendon Press.

Cremona M (2011) Values in EU foreign policy. In M Evans, P Koutrakos (eds) Beyond the Established orders: Policy Interconnections between the EU and the Rest of the World. Oxford: Hurt Publishers.

Cooper F, Stoler LA (2011) Tensions of Empire: Colonial Cultures in a Bourgeois World. University of California Press.

Damro C (2012) Market power Europe. Journal of European Public Policy 19(5): 682-699.

Del Sarto R (2016) Normative Empire Europe: The European Union, its borderlands, and the 'Arab Spring'. Journal of Common Market Studies 54(2): 215-232.

Diez T (2005) Constructing the Self and Changing Others: Reconsidering 'Normative Power Europe'. Millennium: Journal of International Studies 33(3): 613-36.

Diez T (2013) Normative power as hegemony. Cooperation and Conflict 48(2): 194210.

Dunne T, Reus-Smit C (2017) The Globalization of International Society. Oxford: Oxford University Press.

Elgstrom O, Smith M (2006) The European Union's Roles in International Politics. London: Routledge.

European Commission (2000) The Schuman Declaration: 9 May 1950. Available at: https://bit.ly/1ngyVGm.

European Commission (2003a) European Security Strategy: A Secure Europe in a Better World. Available at: http://www.consilium.europa.eu/uedocs/cmsUpload/ 78367.pdf 
Vol. 4, No. 2 Stivachtis: The 'Civilizing' Empire: The European Union and the...

European Commission Communication (2003b) Wider Europe - Neighbourhood: A New Framework for Relations with Our Eastern and Southern Neighbours, 11 March 2003, COM (2003) 104 final.

European Commission (2004) European Neighbourhood Policy, 12 May 2004, COM (2004) 373 final.

European Commission (2008) Report on the Implementation of the European Security Strategy: Providing Security in a Changing World. Available at: https://bit.ly/2 GE8Ctr.

European Commission (2011a) A Partnership for Democracy and Shared Prosperity with the Southern Mediterranean.

European Commission (2011b) A New Response to a Changing Neighbourhood: A Review of European Neighbourhood Policy.

European Commission (2012) Joint statement of José Manuel Barroso, President of the European Commission, and Herman Van Rompuy, President of the European Council on the award of the 2012 Nobel Peace Prize to the EU (2012) Available at: https://bit.ly/2GjPMIS.

European Commission (2015a) Towards a New European Neighbourhood Policy.

European Commission (2015b) EU Global Strategy. Available at: https://bit.ly/1Ugb zka.

Feuer LS (1989) Imperialism and the Anti-Imperialist Mind. New York: Transaction Publishers.

Galtung J (1973.) The European Community: A Superpower in the Making. London: Allen \& Unwin.

Giusti S, Fassi E (2014) The European endowment for democracy and democracy promotion in the EU neighbourhood. The International Spectator: Italian journal of International Affairs 49(4): 112-129.

Gong G (1984) The Standard of 'Civilization' in International Society. Oxford: Clarendon Press.

Gstöhl S (2015) The Contestation of values in the European Neighbourhood Policy: Challenges of Capacity, Consistency and Competition. Paper presented at the EUSA Fourteenth Biennial Conference. Boston, 5-7 March.

Gstöhl S (2016) The contestation of values in the European neighbourhood policy: challenges of capacity, consistency and competition." In S Poli (ed.) The European Neighbourhood Policy - Values and Principles. Abington: Routledge, 58-78.

Kochenov D (2014) The issue of values. In P Van Elsuwege, R Petrov (eds) Legislative Approximation and Application of EU Law in the Eastern Neighbourhood of the European Union: Towards a Common Regulatory Space? London: Rutledge.

Leino P, Petrov R (2009) Beyond 'Common Values' and competing Universals - the Promotion of the EU's Common Values through the European Neighborhood Policy. European Law Journal 15(5): 654-671.

Leonard M (2014) Seven Reasons why the Arab Uprisings are Eclipsing Western Values. European Council of Foreign Relations, 23 January.

Linklater A (2005a) A European civilizing process? In C Hill, M Smith (eds) International Relations and the European Union. Oxford: Oxford University Press.

Linklater A (2005b) Dialogic politics and the civilizing process. Review of International Studies 31: 141-154.

Linklater A (2016) The standard of 'civilization' in world politics. Social Character, Historical Processes 5(2).

Manners I (2002) Normative power Europe. Journal of Common Market Studies 40(2): 235-258. 
Maull HW (1990) German and Japan: The new civilian powers. Foreign Affairs 69(5): 91-106.

Morillas P, Eduard SL (2012) The EU and the Arab Spring, One Year After: A View from the North. EuroMeSCo Brief 39: 1-4.

Orbie J (2009) Europe's Global Role: External Policies of the European Union. Aldershot: Ashgate.

Pridham G (2002a) The European Union's democratic conditionality and domestic politics in Slovakia. Europe-Asia Studies 54(2): 203-27.

Pridham G (2002b) EU enlargement and consolidation democracy in Post-Communist States -formality and reality. Journal of Common Market Studies 40(3): 953-73.

Pridham G (2005) Designing democracy: EU enlargement and regime change in PostCommunist Europe. New York: Palgave.

Prodi R (2000) 2000-2005: Shaping the New Europe. Speech to the European Parliament, Strasburg, 15 February.

Sasse G (2008) The European neighbourhood policy: conditionality revisited for the EU's eastern neighbours. Europe-Asia Studies 60(2): 295-316.

Schimmelfenning F, Engert S, Knobel H (2006) International Socialization in Europe: European Organizations, Political Conditionality and Democratic Change. Basingstoke: Palgrave.

Schwartzenberger G (1955) The standard of 'civilization' in international law. In GW Keeton, G Schwartzenberger (eds) Current Legal Problems. London: Stevens \& Sons.

Schwartzenberger G (1976) A Manual of International Law, $6^{\text {th }}$ edition. London: Stevens $\&$ Sons.

Singh M (2016) The EU's democracy promotion in its 'neighborhood': Renegotiating the Post-Arab spring framework. In NS Romaniuk, M Marlin (eds) Democracy and Civil Society in a Global Era. London: Routledge, 31-42.

Sjursen H (2004) Missed opportunity or eternal fantasy? The idea of a European security and defense policy. In J Peterson, H Sjursen (eds) A Common Foreign Policy for Europe? Competing Visions of the CFSP. London: Routledge.

Stivachtis (2007) The EU as an international actor: 'civilian', 'normative', or 'military' power? In YA Stivachtis (ed.) The State of European Integration. Aldershot: Ashgate, 41-58.

Stivachtis Y (2008) The standard of civilization in contemporary international society: the case of the European Union. Contemporary Politics 14(1): 71-90.

Stivachtis Y, Price C, Habegger M (2013) The European Union as a peace actor. Review of European Studies 5(3): 4-17.

Stivachtis Y (2015) European Union, Conditionality, and Empire. In H Behr, YA Stivachtis (eds) Revisiting the European Union as Empire. London: Routledge, 74-95.

Telo M (2006) Europe, a Civilian Power. New York: Palgrave Macmillan.

Tholens S, Groß L (2015) Diffusion, contestation and localization in post-war states: 20 years of Western Balkans reconstruction. Journal of International Relations \& Development 18: 249-264.

Tocci N (2007) The EU and Conflict Resolution: Promoting Peace in the Backyard. London: Routledge.

Twitchett K (1976) Europe and the World: The External Relations of the European Market. New York: St. Martin's Press.

Watson A (1992) The Evolution of International Society. London: Routledge.

Whitman R (1998) From Civilian to Superpower? The International Identity of the European Union. Basingstoke: Macmillan. 
Vol. 4, No. 2 Stivachtis: The 'Civilizing' Empire: The European Union and the...

Zielonka J (2006) Europe as Empire: The Nature of the Enlarged European Union. Oxford: Oxford University Press.

Zielonka J (2011) The EU as an international actor: unique or ordinary? European Foreign Affairs Review 16: 281-301.

Zielonka J (2013) Europe's new civilizing missions: The EU's normative power discourse. Journal of Political Ideologies 18(1): 35-55.

Zielonka J (2015) The uses and misuses of the imperial paradigm. In H Behr, YA Stivachtis (eds) Revisiting the European Union as Empire. London: Routledge, 45-58. 